\title{
PRIMEIROS DIÁLOGOS NO GRANDE TEMPO
}

\author{
FIRST DIALOGUES IN THE GREAT TIME
}

Ana Maria Funqueira Fabrino*

Universidade de São Paulo, São Paulo, SP, Brasil

Resumo: 0 objetivo deste trabalho é o de oferecer uma sugestão de ensino de literatura para 0 Ensino Médio, recuperando aspectos primitivos de sua historía para buscar uma contextualização de seu conceito e da extensão da importância de seu ensino, pois a literatura pode ser reconhecida como uma das necessidades básicas do ser humano, que fabula e fantasia. Para tal, parte-se de um resgate conceitual com amparo na ideia de cronotopo e do dálogo no grande tempo, de Bakhtin, e na sua exemplificaçã̃o, estabelecendo um diálogo entre algumas formas primitivas de narrativa, os chamados "mitos da criaç̣̃o".

Palavras-chave: cronotopo; diálogo; história; literatura; mitos da criação.

Abstract: The objective of this work is to offer a suggestion of literature teaching at high school recovering primitive aspects of its history to seek a contextualization of its concept and the extension of the importance of its teaching, since the literature can be recognized as one of the basic necessities of the human being, which fables and fantasy. For this, there is a conceptual rescue with support in the idea of cronotope and the dialogue in the great time, from Bakhtin, and in its exemplification, establishing a dialogue between some of the primitive forms of narrative, called "myths of the creation".

Keywords: : Cronotope; Dialogue; History, Literature; Myths of Creation.

* Doutora em Letras pela Universidade de São Paulo - USP, São Paulo, SP, Brasil; anafabrino@terra.com.br 
Linha D'Água (Online), São Paulo, v. 30, n. 2, p. 129-147, out. 2017

\section{Introdução}

Há algumas lacunas no ensino da história da literatura no Ensino Médio brasileiro, que ocorre geralmente apoiado em livros didáticos aprovados pelo Programa Nacional do Livro Didático - como os que ilustram esta pequena análise -, e de acordo com as diretrizes dos Parâmetros Curriculares Nacionais para o Ensino Médio (PCNEM). Esse ensino é oferecido a partir de noções iniciais sobre a arte, sendo a literatura considerada uma forma de expressão artística. Em seguida, são oferecidas algumas funções da literatura, como "fazer sonhar, provocar nossa reflexão, divertir, ajudar a construir nossa identidade, ensinar a viver e denunciar a realidade" (ABAURRE e PONTARA, 2010, p. 24-25). São também lembradas as funções "hedonística e catártica" da literatura (CEREJA e COCHAR, 2009, p. 31). Após oferecer essa contextualização, os livros didáticos passam a exemplificar a linguagem literária a partir de fragmentos de textos literários consagrados pelo cânone ocidental e na sequência começam a tratar da história da literatura, partindo do período medieval, com o Trovadorismo, por volta do ano 1200 de nossa era.

A apreensão sobre o fazer literário a partir desta perspectiva omite (CEREJA e COCHAR, 2009) ou aborda apressadamente (ABAURRE e PONTARA, 2010) toda a produção literária dos períodos anteriores, inclusive a que, ainda segundo o cânone universal, promoveu o advento da literatura, na Grécia antiga, a partir de Homero. Mesmo admitindo que as primeiras narrativas, que tratam de mitos da criação, não sejam exatamente literatura, de acordo com seu conceito restrito, elas representam as primeiras tentativas de buscar respostas para as questões básicas que envolvem a humanidade: quem sou eu, de onde vim, para onde vou, que perpassam milênios de nossa história, cujas primeiras respostas resvalam no maravilhoso e no religioso, campos que oferecem intersecções com o fazer literário até hoje.

Este trabalho busca destacar essa lacuna no ensino de história da literatura, oferecendo uma nova trilha que poderá ser percorrida para enriquecer o processo de aquisição de conhecimentos literários, reforçando algumas premissas presentes no PCNEM, como "analisar, interpretar e aplicar os recursos expressivos das linguagens, relacionando textos com seus contextos, mediante a natureza, função, organização e estrutura das manifestações, de acordo com as condições de produção 
Linha D'Água (Online), São Paulo, v. 30, n. 2, p. 129-147, out. 2017

e recepção" (BRASIL, 2000, p. 95) e também contribuindo para ampliar o repertório de ideias dos estudantes.

Assim, partiremos de uma conceituação de literatura que justifique remontar às primeiras narrativas com o intuito de estabelecer um diálogo no grande tempo (BAKHTIN, 2003) entre as várias possibilidades de narrativas recuperando os cronotopos (BAKHTIN, 2014) da criação (dos deuses e do homem), do dilúvio e do julgamento final, situando a literatura num tempo não linear, mas relativo, e estabelecendo relações entre o próprio tempo e o espaço, este como manifestação de culturas e civilizações.

Para tratar do conceito de literatura e suas intersecções no tempo nos basearemos também em Gilles Deleuze e Félix Guattari (2010), em Antonio Candido (2011) e em Irene Machado (2010). As análises e comparações entre os cronotopos presentes nos textos que tratam dos mitos da criação ancoram-se em Fabrino (2014).

\section{Conceito de literatura}

A construção de um conceito de literatura é inerente ao seu aspecto histórico e perpassa outros conceitos, como o de cultura, estilo, qualidade da obra literária e mesmo esses outros conceitos se transformam, participam do seu devir ou de suas conexões no presente. No conceito de literatura há componentes, que, embora sejam distintos, não são separáveis dele, como a epifania e o efeito catártico. A epifania, (do grego epipháneia, que significa "aparição", "manifestação") é uma "percepção da natureza ou do significado essencial de alguma coisa" (HOUAISS, 2001, p. 1178). É empregado no sentido filosófico para indicar que alguém finalmente conseguiu compreender todos os indícios e atingiu o conceito completo; é quando um pensamento único, inspirado e iluminado acontece, parecendo ter uma força divina, quase sobrenatural.

Já a catarse, segundo Aristóteles (1973), tem um poder purificador e redentor. Para ele, a finalidade da arte é a de ensinar o bem, por isso o herói deve ser enaltecido por suas virtudes, e suas ações devem ser imitadas, em oposição às do vilão, cujas atitudes incorretas devem ser repudiadas e seu castigo serve de exemplo, pois o público, ao se identificar com ele, teme receber igual punição e se sente aliviado 
Linha D'Água (Online), São Paulo, v. 30, n. 2, p. 129-147, out. 2017

por não estar em seu lugar. Esse alívio desencadeia um processo de purificação e faz o público querer imitar apenas as ações virtuosas do herói para também ser recompensado - esse é o efeito catártico ou a catarse, que desencadeia no público esse movimento de identificação, deslumbramento e expurgação, próprio da arte.

Gilles Deleuze e Félix Guattari, na obra O que é filosofia? (2010), tratam da ideia de construção de conceitos e entre eles está o de literatura. Os autores destacam componentes (ou cronotopos, para Bakhtin) que surgem de formas distintas em diferentes obras literárias, mas que criam pontes entre elas (ou, para Bakhtin, estabelecem diálogos), seriam as manifestações de temas recorrentes, de personagens, que, em determinadas obras, apontam para uma coincidência que torna aquela trama e aquela personagem singulares, mas com pontos em comum com outras, promovendo um reconhecimento de aspectos que são traços de todos os seres humanos, com os quais eles se identificam nos recortes apresentados como obras literárias.

É próprio do ser humano uma necessidade de fabulação, de fantasia, que irá permitir a construção de sentidos e a percepção de seu próprio papel em sua história. É na arte literária que há a apreensão de sensações e percepções, pois "o material particular dos escritores são as palavras, e a sintaxe, a sintaxe criada que se ergue irresistivelmente em sua obra e entra na sensação" (DELEUZE e GUATTARI, 2010, p. 198). Deleuze e Guattari (2010, p. 202) citam Bakhtin, provavelmente, referindo-se ao conceito de polifonia, mas perpassam também o conceito de cronotopo ao tratar dos "perceptos" que fazem parte, junto com os "afectos", de um bloco de sensações que se perpetuam, são "seres que valem por si mesmos e excedem qualquer vivido” (DELEUZE e GUATTARI, 2010, p. 194).

Destarte, por meio de palavras, o escritor vivifica uma percepção provocada, não importa em que tempo ou espaço, e a torna presente no processo de leitura, revivendo o momento da enunciação e despertando reações nos leitores, geralmente associadas à epifania, que resgatam traços de humanidade presentes em todos. O romancista é

um vidente, alguém que se torna. (...) Ele viu na vida algo muito grande (...) fazendo estourar as percepções vividas numa espécie de cubismo, de simultanismo, de luz crua ou de crepúsculo, de púrpura ou de azul, que não têm mais outro 
Linha D'Água (Online), São Paulo, v. 30, n. 2, p. 129-147, out. 2017

objeto nem sujeito senão eles mesmos. 'Chama-se de estilos, dizia Giacometti, essas visões paradas no tempo e no espaço' (DELEUZE e GUATTARI, 2010, p. 202).

Bakhtin chamaria essas visões, que para ele dialogam no grande tempo, de cronotopo:

À interligação fundamental das relações temporais e espaciais, artisticamente assimiladas em literatura, chamaremos cronotopo (que significa 'tempo-espaço'). Esse termo é empregado nas ciências matemáticas e foi introduzido e fundamentado como base na teoria da relatividade de Einstein" (BAKHTIN, 2014, p. 211).

As relações num tempo contínuo ocorrem pelas intersecções dos espaços, não necessariamente geográficos, mas culturais e civilizatórios - as manifestações de uma cultura ou civilização ecoam em tempos distintos, em movimentos de ir e vir e esses ecos são ouvidos nas narrativas, encontrando o "simultanismo" de Deleuze e Guattari. Ou, como elucida MACHADO (2010, p. 208),

Bakhtin desenvolveu uma compreensão da representação do tempo segundo um outro encaminhamento. Do ponto de vista da orientação dialógica de sua investigação, buscou nas leis da física, sobretudo nos estudos de questionamento do tempo absoluto, aportes para suas formulações. Assim, em vez de sequência ou duração, o alvo de seu interesse foi a simultaneidade de experiências distintas que emergem em ações, vale dizer, transformações e permanência. Tempo e espaço são, assim, dois lados de um só fenômeno; por conseguinte, implicam-se mutuamente"

Ela continua:

O cronotopo foi concebido como uma forma arquitetônica da narrativa que configura modos de vida em contextos particulares de temporalidades. O tempo, para Bakhtin, torna-se pluralidade de visões de mundo: tanto na experiência como na criação, manifesta-se como um conjunto de simultaneidades que não são instantes, mas acontecimentos no complexo de seus desdobramentos. A pluralidade de que fala Bakhtin só pode ser apreendida no grande tempo das culturas e das civilizações, quer dizer, no espaço (MACHADO, 2010, p. 211). 
Os cronotopos da aventura, do encontro, da praça pública ou da metamorfose, entre alguns citados por Bakhtin, ocorrem em tempos e espaços distintos, mas são reconhecidos no momento em que se estabelece a simultaneidade dada pela enunciação e que evoca o "percepto", materializado na palavra, na literatura. No grande tempo da cultura ou da civilização, o cronotopo da pergunta e da resposta perpetua-se: a cada pergunta, nova resposta, renovando indefinidamente o diálogo e tornando imprescindível a literatura.

A literatura, então, faz-se necessária, pois é uma atividade na qual vozes distintas ecoam e são ouvidas, estabelecendo um grande diálogo no tempo, ouvido em várias circunstâncias, expressando pela linguagem o que se vivencia na sua ausência.

Essa necessidade de literatura existe até mesmo no cotidiano, como a apresenta Antonio Candido em um artigo sobre literatura e direitos humanos, no qual expõe o desfrute da literatura como uma das necessidades básicas do ser humano por ser ela um dos norteadores do próprio conceito de humanidade:

Chamarei de literatura, da maneira mais ampla possível, todas as criações de toque poético, ficcional ou dramático em todos os níveis de uma sociedade, em todos os tipos de cultura, desde o que chamamos folclore, lenda, chiste, até as formas mais complexas e difíceis da produção escrita das grandes civilizações.

Vista deste modo, a literatura aparece claramente como manifestação universal de todos os homens em todos os tempos. Não há povo e não há homem que possa viver sem ela, isto é, sem a possibilidade de entrar em contato com alguma espécie de fabulação.

Assim como todos sonham todas as noites, ninguém é capaz de passar as vinte e quatro horas do dia sem alguns momentos de entrega ao universo fabulado. $\mathrm{O}$ sonho assegura durante o sono a presença indispensável deste universo, independentemente da nossa vontade.

E durante a vigília a criação ficcional ou poética, que é a mola da literatura em todos os seus níveis e modalidades, está presente em cada um de nós, analfabeto ou erudito, como anedota, causo, história em quadrinhos, noticiário policial, canção popular, moda de viola, samba carnavalesco. Ela se manifesta desde o devaneio amoroso ou econômico no ônibus até a atenção fixada na novela de televisão ou na leitura seguida de um romance (CANDIDO, 2011, p. 174-175). 
Tomando a literatura como uma forma de arte que exprime sentimentos, ideias, sonhos e fantasias por meio de palavras, pode-se entender sua perpetuação por tratar de valores universais que transcendem o momento em que foram expressos e permanecem ao longo do tempo. Quando se lê uma obra literária, esses valores são retomados e situados no tempo presente, revivendo-os e travando com eles um diálogo atemporal, no qual os questionamentos acerca da natureza das coisas e do homem encontram respostas que trazem reflexões e deleite, havendo a inserção em um mundo, no qual o sentido da vida tem sido buscado há muito tempo. Por isso a literatura torna-se essencial e se faz necessário compartilhá-la, e esse compartilhamento dá-se por meio de seu ensino.

\section{História da literatura e seu ensino}

Quando a história da literatura é abordada, percebe-se a retomada de vários temas que procuram responder aos desassossegos inerentes a cada época, os quais se repetem ao longo do tempo, travando um diálogo atemporal. Os próprios autores/ videntes não preveem, no momento em que escrevem, a dimensão que sua obra alcançará. BAKHTIN afirma que "as obras dissolvem as fronteiras da sua época, vivem nos séculos, isto é, no grande tempo e, além disso, levam frequentemente (as grandes obras, sempre) uma vida mais intensiva e plena que em sua atualidade" (2003, p. 362, grifo do autor). Por exemplo, nem Cervantes sabia, em seu tempo, que se tornaria o que é hoje e que as leituras e interpretações de sua obra se renovariam a cada época.

Quanto ao seu ensino, vimos que a história da literatura geralmente é introduzida a partir de textos pertencentes ao século XII, com o Trovadorismo, e quase não faz menção ao que vem anteriormente, como se a fabulação e a presença do fantasioso não acompanhassem a humanidade desde seu início. $O$ próprio conceito de literatura prevê uma produção que se encaixa às características pós-concebidas, como se, de repente, o ser humano aprendesse a se expressar pela escrita, desconsiderando toda a produção anterior que não está registrada, pois a tradição oral é apenas relativamente considerada, porque não há provas físicas de sua existência, embora haja evidências de que ela foi a responsável pela manutenção das 
Linha D'Água (Online), São Paulo, v. 30, n. 2, p. 129-147, out. 2017

narrativas que se perpetuaram por um tempo talvez muito maior que aquele deixado nas pistas dos registros.

Dentro dessa perspectiva, Walter Ong (1998) nos explica que a manutenção das narrativas orais foi possível pelo emprego de técnicas mnemônicas, como o ritmo, as aliterações e rimas que compunham os hexâmetros, versos compostos não por alternância entre sílabas átonas ou tônicas, mas por longas e breves, como na música.

Outro método empregado eram as fórmulas, parecidas com nossos atuais provérbios. Porém, a preservação não foi para sempre fiel, havendo modificações de acordo com as novas circunstâncias culturais ou civilizatórias: "Na tradição oral, haverá tantas variantes menores de um mito quantas forem as repetições dele, e a quantidade de repetições pode aumentar indefinidamente" (ONG, 1998, p. 53).É o espaço mudando o tempo.

A escola, por convenção, adota alguns clássicos da literatura universal para serem analisados, geralmente a partir de uma leitura "didatizada" (a tradicional "análise literária”, determinando qual é o enredo, as personagens, o tempo, o espaço, o contexto etc.). Essa análise é pertinente, mas alguns aspectos podem contribuir para torná-la mais enriquecedora, como a percepção dos diálogos entre as próprias obras literárias, sejam nos aspectos temáticos (conteúdo) quanto nos estruturais (composição), mantendo a definição de Bakhtin (2003, p. 262) de gênero, a saber: "tipos relativamente estáveis de enunciados", compostos por três elementos: 1. conteúdo temático - o que é ou pode tornar-se dizível por meio de gêneros; 2. construção composicional - estrutura particular dos textos pertencentes ao gênero; e 3. estilo - configurações específicas das unidades de linguagem derivadas, sobretudo, da posição enunciativa do locutor, conjuntos particulares de sequências que compõem o texto etc. A abordagem do estilo (linguagem) talvez seja mais adequada às aulas dedicadas ao estudo da língua.

Para resgatarmos a dimensão do vácuo que é desconsiderada ao ensinar a história da literatura, traçamos uma retrospectiva, em visão panorâmica, de algumas manifestações literárias que surgiram antes do Trovadorismo ou praticamente simultaneamente, como as canções de gesta, narrativas das aventuras de guerra vividas em tempos passados e as novelas de cavalaria, das quais a lenda de Beowulf é uma das mais famosas. 
Linha D'Água (Online), São Paulo, v. 30, n. 2, p. 129-147, out. 2017

Mais para trás, temos o Livro das mil e uma noites, coletânea de histórias maravilhosas em língua árabe, que é também a língua do Alcorão, cujo texto, embora religioso e não propriamente literário, possui beleza e encantamento, como outros textos religiosos; e antes ainda, encontramos o Mababbarata, o maior poema do mundo e principal épico religioso da civilização indiana.

$\mathrm{Na}$ Europa, temos Virgílio, antes estão Esopo, Eurípedes, Sófocles e Hesíodo, que sucederam a Homero. No Oriente, Confúcio e Sun Tzu, com sua obra milenar $A$ arte da guerra. Recuando ainda mais, temos o Pentateuco, reunião dos cinco primeiros livros da Bíblia; o Enuma Elish, na Babilônia; o Livro dos mortos, no Egito; e a Epopeia de Gilgamesh, também na Babilônia, considerado o mais antigo texto encontrado.

Os textos primitivos, como os quatro últimos citados, travam um diálogo quase aberto com seus antecessores ou predecessores. Nos textos mais modernos, este diálogo passa a ser conhecido por intertextualidade, conceito introduzido por Julia Kristeva (1974, p. 64), inspirada em Bakhtin, ao afirmar que "todo texto se constrói como mosaico de citações, todo texto é absorção e transformação de um outro texto." Assim, a metáfora do diálogo no grande tempo sempre é evocada, seja em palimpsestos, seja em camadas, seja em intertextualidade, a qual ocorre quando, por exemplo, em um romance contemporâneo como Ulisses, de James Joyce, temos o diálogo por meio da menção intertextual ao Ulisses (ou Odisseu) de Homero, personagem da epopeia Odisseia.

Dito isso, a seguir, apresentaremos uma ilustração do diálogo no grande tempo entre textos primitivos, destacando alguns cronotopos, como o da criação dos deuses, a criação do homem, o dilúvio e o julgamento. Trata-se de uma sugestão de como alguns conteúdos podem ser analisados, em uma perspectiva primitiva da história da literatura, para colaborar com a compreensão desse diálogo que as narrativas estabelecem entre si no grande tempo, desde as primeiras histórias conhecidas.

\section{Os primeiros diálogos no grande tempo}

Há algumas características em comum entre as antigas narrativas que ficaram conhecidas como "mitos da criação", como a impossibilidade de delimitar 
Linha D'Água (Online), São Paulo, v. 30, n. 2, p. 129-147, out. 2017

precisamente a época de seu surgimento; a tradição oral e o costume de serem repassadas por gerações; além da forma poética, com versos e rimas, que permitiam a memorização; e os cronotopos, como a criação dos deuses e dos homens, o dilúvio e o julgamento final. A difusão dessas narrativas oralmente por várias gerações fez com que elas sobrevivessem ao tempo e passassem a pertencer ao grande tempo, estabelecendo o diálogo bakhtiniano indelével com as obras que sobrevieram. Os mitos da criação ultrapassaram a barreira do tempo e permanecem instigando.

As primeiras tentativas do homem primitivo de compreender seu papel no mundo estavam fundadas no mito e na religiosidade, sendo necessário evocar os deuses para obter deles favores e proteção. Para evocá-los, o homem primitivo criou rituais sagrados e os realizava seguidos de rezas (O LIVRO das Religiões, 2014, p. 12), lendas e cânticos.

Houve registros de algumas dessas narrativas, mas a maioria se perdeu, restando alguns fragmentos registrados nos mais diversos suportes, como as tábuas de argila quebradas na civilização assírio-babilônica; os rolos de papiro, na egípcia; e as cascas e folhas, na indiana.

Dentre estes registros, temos, na Babilônia, o primeiro compêndio de leis do qual tomamos conhecimento (o Código de Hamurabi) e dois poemas épicos - $A$ epopeia de Gilgamesh e o Enuma Elish. Estes últimos reverberaram em locais e tempos muito remotos, especialmente entre os judeus, na época em que foram exilados de Judá, deportados pelo rei Nabucodonosor - talvez esta seja uma das justificativas para as coincidências ou cronotopos encontrados nas narrativas dessas civilizações. O Livro dos mortos, pertencente à civilização egípcia, apresenta as primeiras inquietações morais ao introduzir o cronotopo do julgamento dos mortos, fato que inspirou, filosoficamente, gregos e romanos e, religiosamente, muitas culturas, em especial a cristã, com a presença do juízo final no livro do Apocalipse, presente no Novo Testamento da Bíblia.

Fazem parte da Bíblia, também, mas agora nos primórdios da cultura hebraica, os primeiros manuscritos que compõem o Pentateuco, pertencente ao Antigo Testamento. A influência da Bíblia na consciência ocidental é sentida até os dias atuais. Havia, nessas obras, a tentativa de oferecer respostas sobre a condição humana, por meio do cronotopo da criação do mundo e dos deuses, que está presente 
Linha D'Água (Online), São Paulo, v. 30, n. 2, p. 129-147, out. 2017

também na Teogonia, de Hesíodo. O cronotopo do dilúvio é recorrente em várias obras, apresentando o arquétipo da água, significando purificação.

Atribui-se à Epopeia de Gilgamesh o marco inicial da literatura, por esse ser o mais antigo texto encontrado. São inscrições em tabuletas de argila com escrita cuneiforme, escrito aproximadamente no ano de 2750 a.C. e composto por 12 cantos com cerca de 300 versos em cada (ANÔNIMO, A epopeia de Gilgamesh, Prefácio, s/d).

Em síntese, há a narração das aventuras de Gilgamesh, o mais célebre rei da Suméria, o qual, graças às suas conquistas materiais e espirituais, era considerado um herói e um deus. Ele era o quinto rei da primeira dinastia de Uruk e seu reinado teria durado 126 anos. É apresentado como filho do rei Lugalbanda e de uma deusa, Ninsuna. Gilgamesh era, assim, um semideus, possuindo dois terços de composição divina e um terço humana, sendo dotado, portanto, de força sobre-humana, o que explicaria sua grandeza.

O semideus viveu muitas aventuras até encontrar o sábio Ut-napishtim, que sobreviveu ao dilúvio e recebeu dos deuses o dom da imortalidade, também desejado por ele. O sábio lhe disse que a morte era inevitável e poderia ser superada se ele passasse em um teste, que incidia em ficar acordado durante seis dias e sete noites. Gilgamesh não obteve êxito no teste e quis voltar para casa. Quando estava de partida, Ut-napishtim revelou-lhe que havia uma planta no fundo do oceano que devolvia a juventude a quem se ferisse nos seus espinhos. Gilgamesh desceu ao fundo do oceano, colheu a planta e, receoso, quis testar seus poderes em um ancião de sua cidade. Porém, uma serpente roubou-lhe a planta durante seu regresso. Chegou exausto a Uruk e contemplou as grandes muralhas que construiu, sua maior obra (ANÔNIMO, A epopeia de Gilgamesh, s/d). As ruínas de Uruk situamse ao sul do atual Iraque.

Podemos observar muitas semelhanças no conteúdo temático, os cronotopos, de A epopeia de Gilgamesh com o texto da Bíblia judaico-cristã: a referência ao dilúvio, o número de dias do teste a que foi submetido Gilgamesh, que coincide com o tempo que Deus levou para criar o mundo (sete dias), a planta roubada por uma serpente, mesmo animal que provocou a queda de Adão e Eva. Esses são os primeiros exemplos do diálogo no grande tempo por meio de cronotopos. 
Linha D'Água (Online), São Paulo, v. 30, n. 2, p. 129-147, out. 2017

Podemos verificar essa semelhança ao analisar a passagem de A epopeia de Gilgamesh que trata da construção da barca que superará o dilúvio:

Oh, homem de Shuruppak, filho de Ubara-Tutu, põe abaixo tua casa e constrói um barco. Abandona tuas posses e busca tua vida preservar; despreza os bens materiais e busca tua alma salvar. Põe abaixo tua casa, eu te digo, e constrói um barco. Eis as medidas da embarcação que deverás construir: que a boca extrema da nave tenha o mesmo tamanho que seu comprimento, que seu convés seja coberto, tal como a abóbada celeste cobre o abismo; leva então para o barco a semente de todas as criaturas vivas (ANÔNIMO, A epopeia de Gilgamesh, s/d, p. 16).

Ao compará-la com o texto bíblico, temos:

Deus disse a Noé:

- Resolvi acabar com todos os seres humanos. Eu os destruirei completamente e destruirei também a terra, pois está cheia de violência. Pegue madeira boa e construa para você uma grande barca. Faça divisões nela e tape todos os buracos com piche, por dentro e por fora. As medidas serão as seguintes: cento e trinta e três metros de comprimento por vinte e dois de largura por treze de altura. Faça uma cobertura para a barca e deixe um espaço de meio metro entre os lados e a cobertura. Construa três andares na barca e ponha uma porta num dos lados. Vou mandar um dilúvio para cobrir a terra, a fim de destruir tudo o que tem vida; tudo o que há na terra morrerá [...]. Também leve para dentro da barca um macho e uma fêmea de todas as espécies de aves, de todas as espécies de animais e de todas as espécies de seres que se arrastam pelo chão, a fim de conservá-los vivos. (BÍBLIA SAGRADA. "Gênesis", 2011, p. 6: 13-20).

O objetivo do Livro dos mortos, obra da antiguidade egípcia, era guiar os mortos para o além, por meio de orações e rituais. Elaborado em rolos de papiro, era colocado nos sarcófagos para que as almas pudessem consultá-lo, quando estivessem diante dos deuses. Seu primeiro título foi "Livro de sair para a luz", e sua escrita data de aproximadamente 1600 a.C. Era formado por "encantos ensinando a 'não morrer de novo no reino dos mortos'e havia instruções sobre como falar, respirar e beber no Além; e também relatos sobre as vidas dos mortos, principalmente, 
seus grandes feitos, que lhes permitiriam obter um bom julgamento de Osíris, o senhor dos mortos"(O LIVRO das Religiões, 2014, p. 59).

Conta a lenda que Osíris foi morto pelo seu irmão invejoso Seth, que partiu seu corpo em pedaços e o espalhou pelo Egito. Néftis e sua irmã Ísis, esposa de Osíris, recolheram os pedaços e o deus Anúbis o recompôs e embalsamou, tornando-o a primeira múmia da história. Enquanto embalsamava, Anúbis entoava encantos que ressuscitaram Osíris, tornando-o o senhor dos mortos, que os julgava e autorizava ou não sua entrada no Aaru, o paraíso.

A tradição ensinou o temor ao julgamento de Osíris; assim, os egípcios passaram a atentar para seu comportamento enquanto vivos e, pela primeira vez na história da humanidade, a existência passou a contar com um viés moral, havendo o respeito para valores como verdade, justiça e dignidade, para que, no final da vida, ao serem julgados, merecessem ir para o paraíso.

Retomando o diálogo no grande tempo, vê-se que o cronotopo do julgamento final também é encontrado na Biblia ao citar o Livro da Vida, no Apocalipse, que pertence ao Novo Testamento, parte que narra os acontecimentos depois da vinda de Jesus Cristo:

Depois vi um grande trono branco e aquele que está sentado nele. A terra e o céu fugiram da sua presença e não foram vistos mais. Vi também os mortos, tanto os importantes quanto os humildes, que estavam de pé diante do trono. Foram abertos livros, e também foi aberto outro livro, o Livro da Vida. Os mortos foram julgados de acordo com o que cada um havia feito, conforme estava escrito nos livros. (BÍBLIA SAGRADA. "Apocalipse”, 2011, p. 20: 11-13).

Outro mito de criação babilônico, o Enuma Elish ("canto do alto") é composto por sete cantos gravados em sete tábuas de argila com cerca de 1.100 versos. (...) A obra é estruturada em cinco temas: a origem dos deuses; o mito de Ea e Apsu; o mito de Tiamat; o mito de criação humana e o hino a Marduque. Na primeira tábua, é narrada a criação dos deuses feita por Apsu, o deus primitivo das águas doces, e Tiamat, a deusa do mar. Ambos se arrependem desse ato, mas os novos deuses, liderados por $\mathrm{Ea}$ (que posteriormente se tornou o deus das águas doces), defendem-se, matando Apsu e atacando Tiamat, que cria um exército de monstros para contra-atacar. Nas tábuas seguintes, há o relato do nascimento de Marduque, filho de Ea, que passa por provações para poder convencer o conselho 
dos deuses de sua capacidade de luta. Ao ser nomeado rei, Marduque tem a permissão para lutar e então mata Tiamat, dividindo o corpo da deusa: uma metade é utilizada para criar a terra e a outra para criar o céu. Marduque é responsável por determinar as funções a serem desempenhadas pelos outros deuses e criar os dias, os meses e as estações do ano. Cria também os homens a partir do sangue de Kingu, principal ajudante de Tiamat, e oferece-os como criados aos deuses. Em retribuição, estes constroem um palácio para Marduque na Babilônia e consagram-no como rei, dando-lhe o poder sobre todas as coisas (FABRINO, 2014, p. 39).

Assim como em A epopeia de Gilgamesh, há várias semelhanças entre o mito da criação narrado no Enuma Elish e a Bíblia, agora no livro de Gênesis, como a ordem em que ocorreu a criação de todas as coisas, começando na luz e terminando no homem, a capacidade criadora da palavra e a divisão do mundo entre o céu e a terra. Verifica-se outro diálogo no grande tempo entre a sexta tábua do Enuma Elish, sobre o cronotopo da criação do homem, e o livro de Gênesis:

Quando Marduque ouviu a palavra dos deuses,

O seu coração despertou-o e ele estabeleceu um plano desenvolto.

Abriu a sua boca e falou para $\mathrm{Ea}$

Aquilo que ele tinha concebido no seu coração lho concedeu:

"O meu sangue eu tomarei e com o osso eu formarei

Farei o homem, para que o homem possa...

Criarei o homem que habitará a terra,

Para que o serviço dos deuses possa ser estabelecido e para que

os seus santuários possam ser construídos [...] (ANÔNIMO. Enuma Elish, 1999, p. 24).

Aí Ele disse: - Agora vamos fazer os seres humanos, que serão como nós, que se parecerão conosco. Eles terão poder sobre os peixes do mar, sobre as aves, sobre os animais domésticos e selvagens e sobre os animais que se arrastam pelo chão. Assim Deus criou os seres humanos; ele os criou parecidos com Deus. (BÍBLIA SAGRADA. Gênesis, 2011, p. 2: 26-27).

Ainda abordando os textos que compõem o Antigo Testamento, acredita-se que o Pentateuco teria sido escrito por Moisés, por volta de 1250 a.C. Segundo Fabrino 
(2014, p. 42), "Pentateuco, do grego pentáteukhos, significa "os cinco rolos" e é assim chamado por conter os cinco primeiros livros da Bíblia. É o mesmo texto da Torá, que traz os ensinamentos da tradição judaica. O primeiro livro do Pentateuco - e, portanto, da Bíblia - é o Gênesis, que relata a criação do mundo, as origens da humanidade (de Adão a Abraão), Noé e o dilúvio e a história dos patriarcas hebreus (Abraão, Isaac e Jacó). (...) Gênesis significa 'geração', 'origem', e corresponde ao princípio da criação dos céus, da terra, da humanidade e de todos os seres."

Acredita-se que o poeta Hesíodo tenha sido contemporâneo a Homero. Aquele é autor de dois poemas notáveis, que foram preservados por inteiro, a Teogonia e Os trabalhos e os dias. Seus textos têm função quase didática e se voltam para as camadas mais humildes da população grega da época, diferentemente de Homero, que se dirigia às classes dominantes (CARPEAUX, 2011, p. 61).

Hesíodo se coloca como sujeito da história, relata e participa do fato relatado, diferentemente de Homero. Seus poemas são vistos como algumas das principais fontes para entender a religião, as técnicas agrícolas, o pensamento econômico, a astronomia e o estudo do tempo na Grécia arcaica. A Teogonia trata da origem do mundo (cosmogonia) e dos deuses (teogonia), desde seu início com Caos, Gaia e Eros, exibindo uma genealogia dos deuses. Acredita-se que o mito da criação de Hesíodo tenha sido inspirado em tradições orientais, como o Enuma Elish babilônico. Essas semelhanças podem ser vislumbradas no diálogo com a primeira tábua do Enuma Elish, contendo os versos que tratam da criação dos deuses primordiais na Teogonia:

Quando nos altos céus não era mencionado,

E a terra embaixo ainda não tinha nome,

E o primevo (primitivo) Apsu, que os criou,

E o Caos, Tiamat, a mãe de ambos

As suas águas foram misturadas umas com as outras,

E nenhum campo fora formado, e não se via nenhum pântano;

Quando nenhum dos deuses havia sido chamado à existência,

E nenhum alcançado um nome, e os destinos tinham sido

ordenados;

Então foram criados os deuses no meio dos céus,

Lahmu e Lahamu foram chamados à existência... 
Linha D'Água (Online), São Paulo, v. 30, n. 2, p. 129-147, out. 2017

As idades (eras ou épocas) aumentaram...

Então Ansar e Kisar foram criados, e dominaram-nos...

Passaram-se muitos dias, então eles trouxeram à existência...

Anu, o seu filho... [...] (ANÔNIMO. Enuma Elish, 1999, p. 3).

Sim, bem pelo primeiro nasceu Caos, depois também

Terra de amplo seio, de todos sede irresvalável sempre, dos imortais que têm a cabeça do Olimpo nevado,

e Tártaro nevoento no fundo do chão de amplas vias,

e Eros: o mais belo entre os deuses imortais,

solta-membros, dos deuses todos e dos homens todos

ele doma no peito o espírito e a prudente vontade (HESÍODO, 1984, p. 132).

O diálogo no grande tempo entre as primeiras narrativas, quando as distâncias eram longas e os deslocamentos trabalhosos, conseguem ser estabelecido com clareza, na recorrência temática, no cronotopos, e até mesmo na estrutura em versos, em uma simultaneidade estarrecedora, criando pontes entre culturas e civilizações ao buscar respostas para vários questionamentos, como: por que surgiram ideias como a criação dos homens a partir de deuses? Qual a necessidade de julgar os mortos? Por que a presença de um deus punitivo que lava a humanidade com as águas do dilúvio? As respostas a essas questões têm sido buscadas até hoje, em nossas aventuras, ou, como afirma CAMPBELL (1997, p. 411), " nos silêncios do nosso próprio desespero".

\section{Para que os diálogos no grande tempo permaneçam ouvidos}

A história da literatura pode ir além da apresentação de autores e obras na linha do tempo - ela pode, também, estimular o diálogo entre as obras fora dessa linha contínua, incentivando a leitura de obras que permanecem vivas nos séculos, isto é, no grande tempo. Vimos que os livros didáticos voltados ao ensino de literatura no Ensino Médio apresentam várias "funções" da literatura.

Dito isso, Harold BLOOM (2011, p. 25) suscita o leitor "a procurar algo que lhe diga respeito e que possa servir de base à avaliação, à reflexão. Leia plenamente, não para acreditar, nem para concordar, tampouco para refutar, mas para buscar 
Linha D'Água (Online), São Paulo, v. 30, n. 2, p. 129-147, out. 2017

empatia com a natureza que escreve e lê”. Essa empatia faz com que o leitor sinta a mesma emoção que está sendo descrita pelo autor, que o toca, emociona, e faz fundir o sentimento do autor com o do leitor, num compartilhamento da experiência estética e existencial, semelhante à ideia de percepto de Deleuze e Guattari (2010) descrita no início deste texto. Há também

as justificativas acadêmicas para ler os clássicos: por meio deles é possível obter informação sobre os valores de um povo, eles colaboram para aumentar o repertório de ideias e para oferecer condições de argumentar com maior convicção e profundidade, compreendendo aspectos culturais e ideológicos que reforçam o senso crítico e despertam a consciência. Mas há, principalmente, a enorme surpresa de nos identificarmos com a voz do outro. Talvez Bakhtin não previsse que este diálogo literário no grande tempo teria como interlocutores leitores, autores, personagens, críticos, todos nós que, ao nos reconhecermos nas histórias, por vezes até parecidas umas com as outras, com descrições de personagens que nos soam familiares, em lugares e tempos parecidos com os nossos ou nos quais gostaríamos de estar, faz-nos crer que elas foram feitas especialmente para nós, a ponto de parecer que falam realmente de nós (FABRINO, 2014, p. 335-336).

As várias vozes ouvidas no grande tempo da literatura transformam o diálogo e os cronotopos em uma sinfonia, cujos acordes ressoam desde o princípio ao infinito, e, ao ensinar literatura, esses acordes são recuperados e continuam ecoando.

\section{Referências}

ABAURRE, Maria Luiza M e PONTARA, Marcela. Literatura - tempo, leitores e leituras. São Paulo: Moderna, 2010.

ANÔNIMO. Enuma Elish - o épico da criação. Retirado de As Sete Tábuas da Criação, Londres: The Book Tree/Luzac and Co., 1999 (1902). Tradução de L.W. King.

ANÔNIMO. A Epopeia de Gilgamesh. Trad.Carlos Daudt de Oliveira. São Paulo: Martins Fontes, s/d.

ARISTÓTELES. Poética. Col. Os Pensadores, volume IV - Aristóteles. São Paulo: Abril, 1973. 
Linha D'Água (Online), São Paulo, v. 30, n. 2, p. 129-147, out. 2017

BAKHTIN, Mikhail. Estética da criação verbal. São Paulo: Martins Fontes, 2003.

Questôes de literatura e estética - a teoria do romance. São Paulo: Hucitec, 2014.

BÍBLIA SAGRADA - nova tradução na linguagem de hoje. São Paulo: Edições Paulinas, 2011.

BLOOM, Harold. Como e por que ler. Rio de Janeiro: Objetiva, 2011.

BRASIL. Secretaria de Educação Média e Tecnológica. Parâmetros Curriculares Nacionais (Ensino Médio) - Linguagens, Códigos e suas Tecnologias. Brasília, 2000. Disponível em http://portal.mec.gov.br/seb/arquivos/pdf/blegais.pdf. Acesso em 03 out 2017.

CAMPBELL, Joseph. O herói de mil faces. São Paulo; Cultrix/ Pensamento, 1997.

CANDIDO, Antonio. O direito à literatura. In: Vários escritos. Rio de Janeiro: Ouro sobre Azul, 2011.

CARPEAUX, Otto M. História da literatura ocidental, volume I. São Paulo: Leya, 2011.

CEREJA, William e COCHAR, Thereza. Português: linguagens. São Paulo: Atual, 2009.

DELEUZE, Gilles; GUATTARI, Felix. O que é filosofia. São Paulo: Editora 34, 2010.

FABRINO, A. M. J. História da literatura universal. Curitiba: Intersaberes, 2014.

HOUAISS, A. e VILlAR, M. de S. Dicionário Houaiss da Lingua Portuguesa. Rio de Janeiro: Objetiva, 2001.

HESÍODO. Teogonia. Estudo e tradução de Jaa Torrano. São Paulo: Roswitha Kempf Editores, 1984.

HOMERO. A Odisseia. Tradução de Frederico Lourenço. São Paulo: Penguin Classics/ Companhia das Letras, 2011.

KRISTEVA, Julia. Introdução à semanálise. São Paulo: Perspectiva, 1974. 
Linha D'Água (Online), São Paulo, v. 30, n. 2, p. 129-147, out. 2017

MACHADO, Irene. "A questão espaço-temporal em Bakhtin: cronotopia e exotopia”. In: PAULA, Luciana e STAFUZZA, Grenissa (orgs.) O círculo de Bakbtin: teoria inclassificável. Campinas: Mercado das Letras, 2010, v. 1, p. 203-234.

O LIVRO das Religiões. Vários autores. Trad. Bruno Alexander. São Paulo: Globo Livros, 2014.

ONG, Walter. Oralidade e cultura escrita: a tecnologização da palavra. Campinas: Papirus, 1998.

Recebido em 06/06/2017.

Aprovado em 15/08/2017. 